\title{
Students' English Structure and Written Competence
}

Palendja Etta Tilana

English Education Study Program, Department of Language and Art University of Bengkulu

palendjaetta@gmail.com

\author{
Wisma Yunita \\ English Education Study Program, Department of Language and Art University \\ of Bengkulu \\ wismayunita@unib.ac.id
}

\section{Zahrida}

English Education Study Program, Department of Language and Art University of Bengkulu

zahrida@yahoo.com

\begin{abstract}
This research aims to investigate the students' English competence, the highest percentage of students' mistake and their difficulties in responding to the TOEFL structure and written expression sections. All of the 6th semester students of the English Education Study Program of Universitas Bengkulu who had passed all structure courses were involved in this research. The data were collected through a TOEFL test and an interview. The results show that majority of the students' English competence was poor. It also reveals that the most difficult topic in grammar section was redundancy. There were two factors that affected the students' performance in redundancy, ambiguity and the interference of first language. In contrast, gerund and infinitives were the easiest topic in grammar section. Simple rules and the most common expression were contributed to the students' performance in gerund and infinitives. In responding to structure and written expression section there were four factors that influenced students' difficulties, poor understanding of grammar, less focus, lack of practice and limited vocabulary.
\end{abstract}

Key words: Students' English Competence, TOEFL Structure and Written Expression Section 


\title{
Journal of English Education and Teaching \\ Volume 3 number 22019 \\ Pp. 180-194
}

\begin{abstract}
ABSTRAK
Penelitian ini bertujuan untuk meneliti kompetensi bahasa inggris mahasiswa, presentase kesalahan tertinggi dan kesulitan dalam menjawab tes TOEFL bagian struktur dan tertulis. Semua mahasiswa semester 6 jurusan pendidikan bahasa inggris di Universitas Bengkulu yang telah mengambil mata kuliah struktur terlibat dalam penelitian ini. Data diambil melalui tes TOEFL dan wawancara. Hasil menunjukkan bahwa mayoritas kompetensi bahasa inggris mahasiswa adalah rendah. Ini juga menunjukkan bahwa topik paling susah di bagian struktur adalah redundancy. Terdapat dua faktor yang mempengaruhi kinerja mahasiswa dalam mengerjakan topik redundancy, keambiguan dan interferensi bahasa pertama. Sebaliknya, gerund dan infinitives adalah topik yang paling mudah di bagian struktur. Aturan yang sederhana dan ungkapan yang paling sering digunakan berkontribusi pada kinerja mahasiswa dalam mengerjakan soal gerund dan infinitives. Terdapat empat faktor yang mempengaruhi mahasiswa dalam menjawab bagian struktur dan tertulis, kurangnya pemahaman tentang struktur, kurang fokus, kurangnya latihan dan kosakata yang terbatas.
\end{abstract}

Kata Kunci: Kompetensi Bahasa Inggris Mahasiswa, TOEFL bagian struktur dan tertulis

\section{INTRODUCTION}

English competence is very important in today's world. Many universities, agencies and other institutions use TOEFL scores to evaluate English competence. A number of universities determine TOEFL score as the graduation standard requirement in Indonesia. English Department Program in Universitas Bengkulu set a minimum requirement TOEFL Score, 450 to take their thesis exam. However, the students find it difficult to do the TOEFL test, especially in structure and written expression sections (Mahmud, 2014). Wright and Sukur (2012) stated that one big common problem for students of the ITP test is sections 2, Structure and Written Expression, furthermore, students often feel stressed with this part. Based on the data from English Education Study Program of Universitas Bengkulu, there are only 27 students from 77 students who pass the minimum score, 450. The test result shows that structure and written expression is the lowest among other sections in the 
TOEFL test, listening and reading. Based on the researcher observation in the classroom, many students find it difficult in answering structure and written expression sections because of two factors, limited vocabulary and poor understanding of grammar. So, this proves that structure and written expression sections is the most difficult part in the TOEFL test.

Descriptive research was applied in this research. Mixed method research was used to get detailed data for this research. The participants involved in this research were all of the 6th semester students of the English Education Study Program of Universitas Bengkulu who had passed all structure courses. This research was used two instruments, a TOEFL test and an interview. The TOEFL test was taken from Barron's Practice Exercises for the TOEFL: 6th edition (2007). In this TOEFL test, it categorized into two sections, the first section was 25 questions about incomplete sentences and the second section was 35 questions about sentence correction. Then, the test was distributed to the students. From the TOEFL test' results, the researcher analyzed the percentage of students' English competence into four categories; excellent, good, fair, poor. An interview was done to the students who placed in poor category. The students were asked the reasons behind their difficulties in responding to the TOEFL structure and written expression. The students' answers were written into transcript. The transcript was analyzed by using coding technique.

Based on the explanation above, the researcher wants to conduct a research to find out students' English competence in the TOEFL structure and written expression sections, the highest percentage of the students' mistake in the Structure and Written Expression sections, also whether there are some factors influencing the difficulties. The research is entitled "Students' English Structure and Written Competence". 


\section{LITERATURE REVIEW}

English competence can be defined as ability to use English in written and spoken. Chamber (2007) states that language competence as the language ability or ability in language use. English competence is divided into four skills, listening, reading, speaking and writing. A test intended to measure students' knowledge and skill. In the same line, Sudijono (2011) states that in general, the test has two functions; as a measure of the students and as a means of measuring the success of teaching program. In addition, there are different types of test. Each types of test have its own purposes. Brown (2008) classifies the type of test into five categories; proficiency test, diagnostic test, placement test, achievement test, language aptitude test. To measure students' English competence, TOEFL is usually used, which part of proficiency test. TOEFL is the major of English language test in the world. TOEFL is probably the most common academic English test worldwide. Warfield, Laribee \& Geyer (2013) stated that TOEFL is highly recognized language testing in English which is internationally recognized and respected. There are three types of TOEFL test as proposed by Sharpe (2013) the Paper-Based TOEFL (PBT), the Computer-Based TOEFL (CBT), and Internet-Based TOEFL (IBT). PBT and CBT are tested four skills, listening, structure and written expression, reading and writing skills while IBT is tested reading, listening, speaking and writing.

There are two types of questions in structure and written expression sections. Phillip (2001) states that the first type is incomplete sentence in structure section and the second is sentence correction in written expression section. In structure section, the students will be asked to fill in the blank sentence to make it correct. In written expression section, the students will be asked to look for the error in the sentence. 


\section{Previous Studies}

There are some relevant studies related to this research. The first study was conducted by Nurhayati (2016) entitled "An Analysis of Students' Strategies in Answering TOEFL". The results showed that the TOEFL score of the eighth semester students of STKIP Setia Budhi was low. The second study was conducted by Hajri (2018) entitled "An Analysis of Difficulties in Answering Structure and Written Expression of TOEFL Made by English Students of Universitas Negeri Padang". This study investigated that there were three 3 the most difficult items; negation, reduced form, and parallel structure items. The reasons behind the students' mistakes were ignorance, careless, dubious, oblivious and miscast. The first two reasons were the biggest causes of students' mistakes. The last study was conducted by Mayuasti (2018) entitled "Students' Ability in the TOEFL-Like Structure Subtest (A Study At STKIP PGRI Of West Sumatera). This research showed that majority of the students is placed in the low level.

Based on some previous studies above, the researcher conducted similar research related to structure and written expression sections. The differences between those researches and this research are the subject is the sixth semester students of the English Education Study Program of Universitas Bengkulu. This research use different instruments from previous studies above, interview. Then, this research focuses on students' English competence, not only the difficulties in responding structure and written expression.

\section{RESULT AND DISCUSSION}

\section{Result}


This research reveal the students' English competence in the TOEFL structure and written expression sections by giving the students' TOEFL test and interviewing the students on the reasons behind their difficulties in the TOEFL structure and written expression. The result of each question would be explained as follows:

1. Students' English Competence in the TOEFL Structure and Written Expression

Table 1.1

Percentage of Students' English Competence in the TOEFL Structure and Written Expression

\begin{tabular}{|c|c|c|c|}
\hline $\begin{array}{c}\text { Percentage of } \\
\text { Students' Correct } \\
\text { Answer } \\
(\%)\end{array}$ & Categories & $\begin{array}{c}\text { Number of } \\
\text { Students }\end{array}$ & $\begin{array}{c}\text { Percentage } \\
\text { (\%) }\end{array}$ \\
\hline $80-100$ & Excellent & 0 & 0 \\
\hline $60-79$ & Good & 3 & 4 \\
\hline $50-59$ & Fair & 29 & 56 \\
\hline $0-49 \quad$ Poor & 41 & 100 \\
\hline \multicolumn{2}{|c|}{ Total } & 73 & \\
\hline
\end{tabular}

From the result displayed in table 1.1, none of the students were placed in excellent category. On the other hand, there were 3 students or $4 \%$ were placed in good category. 29 students or $40 \%$ were placed in fair category while 41 students or $56 \%$ were placed in poor category. It is apparent that majority of the students' English competence were in poor category.

The students' English Competence in each of the TOEFL structure and written expression sections topics were varied. Table 1.2 presents the percentage of students' English competence in each of the TOEFL structure and written expression sections. 
Table 1.2

\begin{tabular}{l|c|c|c|}
\hline $\begin{array}{l}\text { Percentage of Students' English Competence in Each of the TOEFL Structure } \\
\text { and Written Expression Sections Topics }\end{array}$ & $\begin{array}{c}\text { Number of } \\
\text { Questions }\end{array}$ & $\begin{array}{c}\text { Percentage of } \\
\text { students' correct } \\
\text { answer } \\
\text { Structure Topics }\end{array}$ & $\begin{array}{c}\text { Percentage of } \\
\text { students' } \\
\text { incorrect answer } \\
\text { (\%) }\end{array}$ \\
\hline $\begin{array}{l}\text { Gerund and } \\
\text { Infinitives }\end{array}$ & 7 & 58 & 42 \\
\hline $\begin{array}{l}\text { Subject Verb } \\
\text { Agreement }\end{array}$ & 5 & 54 & 46 \\
\hline $\begin{array}{l}\text { Sentences and } \\
\text { Clauses }\end{array}$ & 5 & 53 & 47 \\
\hline Connectors & 5 & 52 & 48 \\
\hline Word Forms & 12 & 47 & 53 \\
\hline Auxiliary Verbs & 5 & 44 & 56 \\
\hline Comparison & 5 & 43 & 57 \\
\hline Point of View & 5 & 42 & 58 \\
\hline Parallel Structure & 5 & 41 & 59 \\
\hline Redundancy & 6 & 34 & 66 \\
\hline
\end{tabular}

It is clearly shows in table 1.2 that students' English Competence in each of the TOEFL structure and written expression sections topics were varied from one topic to another topic. The highest percentage with correct answer was gerund and infinitives, amounting to $58 \%$ while the lowest correct answer was redundancy, $34 \%$.

2. The Highest Percentage of the Students' Mistakes in the TOEFL Structure and Written Expression Sections

Based on the test result from the highest percentage of the students' mistakes in the TOEFL structure and written expression sections in each topic, redundancy was the highest percentage with 
incorrect answer. This topic consisted of six questions. The descriptions of this topic can be seen in the following table:

Table 2.1

The Highest Percentage of the Students' Mistake in the TOEFL Structure and Written Expression Sections Based on Topic

\begin{tabular}{|c|c|c|c|c|c|}
\hline $\begin{array}{c}\text { Structure } \\
\text { Topic }\end{array}$ & $\begin{array}{c}\text { Items } \\
\text { Number }\end{array}$ & \multicolumn{2}{|c|}{$\begin{array}{c}\text { Correct } \\
\text { Answer }\end{array}$} & \multicolumn{2}{c|}{$\begin{array}{c}\text { Incorrect } \\
\text { Answer }\end{array}$} \\
\cline { 3 - 6 } & & $\begin{array}{c}\text { Number of } \\
\text { Students }\end{array}$ & $\begin{array}{c}\text { Percentage } \\
\text { (\%) }\end{array}$ & $\begin{array}{c}\text { Number of } \\
\text { Students }\end{array}$ & $\begin{array}{c}\text { Percentage } \\
\text { (\%) }\end{array}$ \\
\hline \multirow{5}{*}{ Redundancy } & 24 & 15 & 21 & 58 & 79 \\
\cline { 2 - 6 } & 25 & 33 & 45 & 40 & 55 \\
\cline { 2 - 6 } & 57 & 20 & 27 & 53 & 73 \\
\cline { 2 - 6 } & 58 & 12 & 16 & 61 & 84 \\
\cline { 2 - 6 } & 59 & 42 & 58 & 31 & 62 \\
\hline
\end{tabular}

Table 2.1 presented the percentage of correct answer from six questions in redundancy. There were six items considered as the most difficult questions, item number 24, 25,57,58,59 and 60. Based on all items, item number 5, 10 and 47 considered as the most difficult questions. Item number 5 was pronouns, item number 10 was auxiliary verb and item number 47 was point of view. From the students' answers in interview, there were two factors identified as the causes of the students' performance in redundancy. Ambiguity and the interference from first language appeared to influence their performance. It can be seen from the students' statements as follows:

"It is confusing for me to identify which word should be removed. There are so many ambiguous words in those sentences" (R.S) 


\section{Journal of English Education and Teaching \\ Volume 3 number 22019}

Pp. 180-194

"When I am speaking in English, I am still interfered by grammatical pattern of Indonesian, for example, using more than one word in the same function to make it clear and it is difficult to find which words are redundant in English sentences" (M.I.S)

In contrast to previous results, gerund and infinitives were the lowest percentage with incorrect mistake, it means that gerund and infinitives were the easiest topic among others. There were two factors that influenced the students' performance in gerund and infinitives, simple rules and the most common expression as can be seen in the following statements:

"I think gerund and infinitives rules are easy to remember. The rules are simple which make it easier to learn" (S.D)

"Gerund and infinitives are used to describe the whole activity which means these expressions are commonly used in daily conversation. I think gerund and infinitives are easy to learn because it is often used in conversation than others expression" (R.A.F)

3. Factors Influencing the Students' Difficulties in Responding to the Structure and Written Expression sections in the TOEFL

From two questions asked to the students who got poor category, there were four factors behind the students' difficulties in answering the TOEFL structure and written expression sections. The students said that their poor understanding of grammar was the main problem in answering grammar sections in TOEFL test. It can be seen from the students' statements as follows: 


\section{Journal of English Education and Teaching \\ Volume 3 number 22019 \\ Pp. 180-194}

"My grammar is not good. I think poor understanding of grammar is the main problem in answering structure and written expression sections" (T.O)

"I am still confused about grammar. For me, grammar is considered difficult to learn. I do not have a good comprehension in grammar." (H.T.W)

Some students also answered that less focus in doing the test as one of the factors influencing their difficulties in answering grammar sections, as can be seen in the following excerpts:

"The test was taken during study break. It is quite difficult to concentrate." (D.N)

"I can't focus in doing the TOEFL test because the time is very short. I have another class to attend." (A.N)

Some students mentioned that their lack of practice in doing the grammar test in structure and written expression section made the students facing difficulties, as can be seen in the following statements:

"I rarely practice to do the TOEFL test. I can't answer the TOEFL test in very short time and it might affect in choosing the correct answer." (R.A)

"I did not familiar with the TOEFL test, so I can't manage the time properly. I need more time to do the test. I think lack of practice is one of the factors that influence in answering structure and written expression." (M.R) 
The last factor that influences the students in responding to the structure and written expression sections was limited vocabulary. The students mentioned that they did not know certain words' meaning in English:

"There are so many unfamiliar words. I do not know the meaning of those words." (D.N)

"I only know common vocabulary. I do not recognize those unfamiliar words." (F.G.D)

\section{Discussion}

Based on the results above, it can be stated that the average of students' English competence was poor. More than half of the students were placed in poor category. Similarly, Mayuasti (2018) in her study found that majority of the students in structure and written sections are placed in low level. Nurhayati (2016) also found in her study that the students' TOEFL score in structure and written expression sections is low.

Redundancy was found to be problematic in majority of the students. In the TOEFL test, there were six questions about redundancy, item number $24,25,57,58,59$, and 60 . This topic got the highest percentage with incorrect answer. It was an evident that redundancy considered as the most difficult topic among others. Among all items, item number 5, 10 and 47 considered as the most difficult questions. Item number 5 was pronouns, item number 10 was auxiliary verb and item number 47 was point of view. Hambali (2008) stated that students will have problems in answering the TOEFL structure and written expression sections. Those problems included (1) identifying verbs, (2) identifying the correct word order of subject and verb in a noun clause, and (3) identifying words with derivation and function. Similarly, the students had problems in identifying redundancy, word forms, auxiliary verb and point of view which were part of verbs and words function. 
Since redundancy is the highest percentage with incorrect answer, there are two factors contributing to the students' mistake. The first is ambiguity. The students seem to have problem in identifying which unnecessary word is redundant, it might happen because the difference between Indonesian and English grammar pattern. Then, the second factor is interference of first language. The students probably accustomed to using their first language sometimes while they are speaking in English. The interference may occur in grammar pattern since Indonesian and English grammar pattern are different. They also said that using more than one word or repetition word is very common in Indonesian, it could be ambiguous when it comes to identify redundant words in English. Mira (2018) in her study found that superfluous expression or using more than one word in a sentence is one of types of interference of the Indonesian students when speaking English. Similarly, Syarif (2014) in her study also found that grammatical interference affect the students' ability in English.

In contrast, gerund and infinitives are the lowest percentage with incorrect mistake. Simple rules and most commonly used expression are factors contributing to gerund and infinitives which considered as the easiest question among all topics. The students may use gerund and infinitives often in daily conversation when they are speaking English. They probably find gerund and infinitives in every aspect of English. It is in the line with Schwartz \& Causarano (2007) who stated that gerund and infinitives are high frequently used in English. It means that gerund and infinitives are very common in English conversation.

However, there are some factors behind the poor achievement of the students in the TOEFL test. The first is poor understanding of grammar. The students probably do not have well understanding about the sentences' structure and format. They lack of practice and do not relearn the grammar material. Hajri (2018) in his study found that the reason behind the students' mistakes in answering structure and written expression was lack of grammar 


\section{Journal of English Education and Teaching \\ Volume 3 number 22019}

Pp. 180-194

knowledge. Then, less focus also influenced the students' performance during the test. The test was taken during their study breaks. The students still had some classes to attend so they got distracted. They also thought the time was enough to answer all questions. It was quite difficult to focus for them because of those reasons. The next reason that might account for this matter is the students' lack of practice. The students did not familiar with the TOEFL test and they could not manage their time to do the test properly. So, the students did not read the questions carefully. It is in the line with King and Stanley (2006) who state that majority of the students fail in grammar sections of TOEFL because of their time management. The last factor that influence the students in answering structure and written expression sections is limited vocabulary. The students have to struggle with unfamiliar vocabularies. Hence, the students felt difficult to answer the questions because they did not understand the words' meaning. Akbari (2008) stated "without vocabulary speakers cannot comprehend meaning and communicate with each other in a particular language". It clearly shows that mastering vocabulary could influence the students' performance in answering structure and written expression sections.

\section{CONCLUSION AND SUGGESTION}

\section{Conclusion}

It was found that the majority of the students were placed in poor category. From the test results, the researcher discovered that the most difficult topic in structure and written expression was redundancy. There are two factors influencing the students' failure in redundancy, ambiguity and the interference of first language. Meanwhile, gerund and infinites are considered as the easiest questions among all items. Simple rules and the most common expression are two factors influencing students' performance in gerund and infinitives. The factors which contribute to the students' difficulties in doing the TOEFL test come from several things, the first was poor 


\section{Journal of English Education and Teaching \\ Volume 3 number 22019 \\ Pp. 180-194}

understanding of grammar, followed by less focus then lack of practice and limited vocabulary. These factors could influence their English competence in the TOEFL test quite significantly.

\section{Suggestion}

Based on the conclusion above, there are some suggestions that can be offered. The first is for the students. The students should be aware of the usage of all topics in the TOEFL test and do more exercises by reading a lot of books related to the TOEFL to enrich their understanding in each skill. The second, for the lecturers. It is suggested to provide detail information related to strategies in answering the TOEFL test. The lecturers should explain more detail about grammar materials. The third, for the institution. It is suggested to add TOEFL course in order to improve students' English competence in the TOEFL test. The last suggestion is for future researcher. It is recommended to conduct similar research to English department students from another university. Then, the researcher strongly suggests taking the TOEFL test in the day which students do not attend lectures. So, the students become more focused on the test. 


\section{Journal of English Education and Teaching \\ Volume 3 number 22019 \\ Pp. 180-194}

\section{REFERENCES}

Akbari, O. (2008). Teaching Vocabulary Items through Contextualization and Picture to Elementary Iranian EFL Students. Asian EFL Journal, 10(3), 5377.

Brown, D. (2008). Teaching by Principles, An Interactive Approach to Language Pedagogy. London: Pearson Longman.

Chamber, C. G. (2007). Competition during Second-Language Listening: Sentence Context, but not Proficiency, Constrains Interference from the Native Lexicon. Journal of Experimental Psychology: Learning, Memory, and Cognition, 35(4), 1029-1040.

Hajri, T. (2018). An Analysis of Difficulties in Answering Structure and Written Expression of TOEFL Made By English Students of Universitas Negeri Padang. Journal of English Language Teaching, 7(1), 1-13.

Hambali, M. (2008). Shortcut Strategies in Analyzing Sentence Structures in TOEFL. Jurnal Bahasa dan Sastra, 9(2), 82-88.

King, C., \& Stanley, N. (2006). Building Skills for the TOEFL, Second Edition. London: Thomas Nelson and Sons Ltd.

Mahmud, M. (2014). The EFL Students' Problems in Answering the Test of English as Foreign Language (TOEFL): A Study in Indonesian Context. Theory and Practice in Language Studies, 4(12), 2581-2587.

Nurhayati, N. (2016). An Analysis of Students' Strategies in Answering TOEFL. The Journal of English Language Studies, 1 (1), 10-18.

Mayuasti, M. (2013). Students' Ability in the TOEFL-Like Structure Subtest (A Study at STKIP PGRI of West Sumatera). Jurnal Pelangi, 6 (1), 1-10.

Schwartz, M., \& Causarano, P.L. (2007). The Role of Frequency in SLA: An Analysis of Gerunds And Infinitives in ESL Written Discourse. Arizona Working Papers in SLA \& Teaching, 14(2), 43-57.

Sharpe, P. J. (2013). TOEFL iBT ; 14th Edition. New York: Barons Education Series. Warfield, W. L. R. \& Geyer, R.W. (2013). Examining Results and Establishing Benchmark Data from the TOEFL ITP Test. American Academic \& Scholarly Research Journal, 5(3), 191-198.

Wright, S. W. \& Sukur S. G. (2012). Soal-Soal Grammar TOEFL. Yogyakarta: Kalarana Press. 